\title{
PARIS, 27 DE OUTUBRO DE 1940
}

Shirley Barbosa das Porto ${ }^{1}$

1. Professora Adjunta III (Unidade Acadêmica de Letras). Universidade Federal de Campina Grande-PB. E-mail: sbportoneves@gmail.com

Recebido em: 21/06/2021

Aprovado em: 21/07/2021

Todo o conteúdo deste periódico está licenciado com uma licença Creative Commons (CC BY-NC-ND 4.0 Internacional), exceto onde está indicado o contrário.

\section{Paris, 27 de outubro de 1940}

Era da porta entreaberta que Marie-Anne Gebert observava sua avó enquanto pensava que sempre achara a história naquela foto carregada de mistérios. A penumbra no antiquado quarto, a falta de ventilação daquela área da casa e a mulher que segurava a gasta fotografia preto e branco em seu colo, molhada por suas lágrimas, compunham uma cena carregada por dores de momentos ainda vívidos na alma da velha senhora.

Mal contada por outros, nunca pela protagonista, a narrativa que circundava a fotografia sempre lhe instigara curiosidade e receio. Gostaria compreender as razões para aquela mulher estar sempre atormentada. Parecia ter ancorado a própria vida naquele dia 27.

Sobre a foto Marie-Anne sabia, por uma marcação em lápis, que havia sido tirada por um fotógrafo de rua no Café De La Rotonde, no final da tarde daquele outubro de 1940. Por sinal, mês que, de modo atípico, fizera um frio absurdo em Paris. Os jornais franceses noticiaram $1^{\circ} \mathrm{C}$ no estranho outono, numa semana que em anos anteriores a mínima fora de $5^{\circ} \mathrm{C}$. Em junho a cidade havia sido tomada pelo exército alemão, talvez esses eventos fossem o motivo para o local estar praticamente vazio.

Não foram dias fáceis aqueles. O drama da ocupação escancarava a polarização dos franceses que, numa turbulência emocional e factual, de um lado se colocavam como colaboracionistas do nazismo e do outro como resistência. Os primeiros, pela adesão às ideias do marechal Pétain que desejava uma Revolução Nacional sob o lema trabalho, família e pátria, denunciavam a localização de judeus por meio de cartas anônimas ao III Reich. Em contraponto, a resistência tentava se organizar, mas era encolhida pela pauta alemã que, avalassaladora em sua implementação, pulverizava a ação, deixando espaço e tempo apenas 
para a reatividade que quase não lograva êxito. A família Gebert não se furtara ao seu lugar na história, Marie-Anne bem sabia.

Na gasta imagem, Jácomo Ibarra, em pose professoral, acompanha a jovem Louise. Viera para dar sua última aula antes de uma viagem que não explicara para onde seria. Em despedida levou a garota para seu último passeio-aula, concluído, como sempre, por uma conversa amena acompanhada de chá com biscoitos e o olhar distraído dos dois para o movimento dos carros. Sobre a viagem surpresa, disse apenas que era necessário empreender busca por um lugar mais ameno, Paris se tornara um lugar difícil para professores, mais ainda sendo ele judeu.

Ao término dessas palavras um carro do exército alemão parou e deu voz de prisão ao senhor Ibarra. Ele calmamente olhou para a menina, pediu para pagar a conta e se despediu com a retirada do chapéu, um aceno de cabeça e um auf wiedersehen frau Gebert. 